UDK 327:623.45

Biblid 0543-3657, 71 (2020)

God. LXXI, br. 1179-80, str. 23-47

izvorni naučni rad

Primljen: 6.6.2020.

doi: https://doi.org/10.18485/iipe_mp.2020.71.1179_80.2

\title{
Nuklearna deproliferacija i politika EU prema neširenju oružja za masovno uništenje u kontekstu odnosa prema Indiji, Pakistanu, Iranu i Severnoj Koreji
}

${ }^{1}$ Autor je istraživač saradnik u Institutu za međunarodnu politiku i privredu, Beograd, e-mail: bogdan.stojanovic@diplomacy.bg.ac.rs

Rad je nastao u okviru naučnoistraživačkog projekta „Srbija i izazovi u međunarodnim odnosima 2020. godine“", koji finansira Ministarstvo prosvete, nauke i tehnološkog razvoja Republike Srbije, a realizuje Institut za međunarodnu politiku i privredu tokom 2020. godine.

\section{SAŽETAK}

Cilj ovog rada je prikaz aktivnosti Evropske unije na polju sprečavanja širenja oružja za masovno uništenje. Pored analize institucionalnih i pravnih mehanizama uspostavljenih od 2003. godine pa nadalje, istražuje se i praktičan učinak Evropske unije u sprečavanju proliferacije oružja armagedona. Neujednačena uloga i ostvareni rezultati u različitim kriznim žarištima poput Severne Koreje, Irana, Indije i Pakistana, ostavlja prostor za različite prognoze budućeg delovanja EU. Dobra polazna osnova i bazični konsenzus svih članica, kada je reč o širenju oružja za masovno uništenje, daju razlog za optimizam prilikom analize. Iz tog razloga rad istražuje odnos između uspostavljenih kapaciteta, praktičnih politika i budućih poprišta izbijanja kriza u vezi sa širenjem oružja za masovno uništenje.

Ključne reči: Evropska unija, oružje za masovno uništenje, proliferacija, nuklearni program, Severna Koreja, Iran, Indija, Pakistan. 


\section{Uvodne napomene}

Oružje za masovno uništenje ${ }^{2}$ (dalje: OMU) promenilo je prirodu rata, ali i međunarodnih odnosa uopšte. Na neki način, o oružju za masovno uništenje može se govoriti od srednjeg veka, kada je pojavom barutnog oružja masovno uništavana protivnička strana koja ga nije posedovala. Ipak, OMU se pre svega odnosi na period od Prvog svetskog rata, kada se prvi put aktivno u ratu koristi hemijsko naoružanje (iperit i fozgen), pa do danas kada postoje najrazličitiji vidovi istrebljivačkih sredstava poput termonuklearnih bombi, sarina, antraksa i mnogih drugih hemijskih i bioloških agenasa koji uz adekvatnu isporuku mogu istrebiti stotine hiljada, čak i milione ljudi u kratkom vremenskom intervalu.

Tokom ere Hladnog rata u fokus pažnje dospelo je nuklearno naoružanje i ravnoteža straha između Sjedinjenih Američkih Država (dalje: SAD) i Sovjetskog Saveza (dalje: SSSR). ${ }^{3}$ Nuklearni klub danas broji devet država, ${ }^{4}$ a mogućnost da se on proširi sa tehnološkog aspekta postoji poznajući činjenicu da više od 40 država sveta danas poseduje civilne nuklearne programe, od kojih se pojedini mogu preusmeriti u vojne svrhe. Kraj Hladnog rata i nestanak sovjetskog "prekrivača“, jačanje fenomena globalizacije, krunjenje državnog suvereniteta koji je "napadnut" odozdo (od strane unutardržavnih grupa i organizacija) i odozgo (nadnacionalnim integracionim aranžmanima), "privatizacija nasilja“, kompresija vremena i prostora, učinili su znanje i robu, pa tako i oružje za masovno uništenje, dostupnijim. Fenomen poznat kao „globalizacija“, nakon okončanja Hladnog rata dobija na intenzitetu. Svet je postao "manji“ $\mathrm{i}$ isprepletaniji nego ikada $\mathrm{u}$ istoriji. Informacije, znanje, novac, usluge, prelaze hiljade kilometara $\mathrm{u}$ deliću sekunde. Jednostavno, posle Hladnog rata postoje povoljniji uslovi za proliferaciju (širenje) svih vidova oružja za masovno uništenje. Evropska unija (dalje: EU) je od svog nastanka težila da učestvuje u svetskim bezbednosnim zbivanjima i doprinese međunarodnom miru i stabilnosti. $U$ domenu sprečavanja širenja OMU, može se zapaziti da je EU sve do 2001. godine i terorističkog napada na SAD imala vrlo skroman učinak na tom polju. Taj događaj je osvešćujuće delovao na EU koja je shvatila da nedržavni akteri mogu naneti nesagledivu štetu i najmoćnijim državama sveta. Teroristički akti oružjem za masovno uništenje mogli bi prouzrokovati višemilionske žrtve, te je EU odlučila da sprečavanje širenja tog oružja uvrsti

\footnotetext{
${ }^{2}$ Termin nije u potpunosti odgovarajući jer nervni gasovi, neutronske bombe ili biološko oružje pre svega ubijaju, a ne uništavaju. Prikladnije je stoga govoriti o oružju za masovno ubijanje, mada je i prvi termin u redu kada se govori o uništenju u kontekstu ljudskih života, a ne materijalne štete.

${ }^{3}$ Više o američko-sovjetsko nuklearnoj ravnoteži u: Dragan Petrović i Bogdan Stojanović, Ravnoteža nuklearne moći SAD i Rusije (SSSR), Pešić i sinovi, Beograd, 2012.

${ }^{4}$ SAD, SSSR, Velika Britanija, Francuska, Kina, Izrael, Indija, Pakistan i Severna Koreja.
} 
u svoju listu prioriteta. Prekretnica u delovanju na tom planu načinjena je decembra 2003. godine kada je Savet EU usvojio Evropsku strategiju bezbednosti i Evropsku strategiju protiv širenja oružja za masovno uništenje (dalje: Strategija OMU).

\section{Širenje oružja za masovno uništenje kao pretnja bezbednosti EU}

Situacija da terorista zaražen smrtonosnim virusom prenosivim vazduhom koji nije detektabilan dođe na bilo koji evropski aerodrom, koji dnevno ima više stotina letova i kroz koji na dnevnoj bazi prodefiluje stotine hiljada ljudi, priđe nekoliko šaltera i zarazi šalterske službenice koje imaju kontakt sa hiljadama ljudi koji dalje zaraze još desetine hiljada, nije potpuno $\mathrm{u}$ domenu naučne fantastike. Globalni terorizam koji se danas ističe kao jedna od najvećih pretnji svetskoj bezbednosti, zaista može načiniti nesagledivu ljudsku i materijalnu štetu najmoćnijim državama sveta. Međutim, za takav poduhvat potrebno im je oružje sposobno za masovno ubijanje, koje ne zahteva brojne armije, avione i tenkove, već se na relativno jednostavan način aktivira likvidirajući stotine hiljada $\mathrm{u}$ jednom trenu. Terorista opremljen nuklearnom „kofer bombom“ mogao bi da ušeta $u$ evropsku prestonicu i detonira bombu. Zastrašivanje kroz sistem ravnoteže nuklearne moći ne funkcioniše naspram „neprijatelja bez države“ iz razloga što je meta za odmazdu nepoznata. ${ }^{5}$

Svet se naglo ubrzao, a nestankom sovjetskog bezbednosnog kišobrana buknuli su brojni etnički i teritorijalni sporovi na prostoru koji je do tada bio pod direktnom ili indirektnom kontrolom Moskve. Teritorija nekadašnjeg Sovjetskog Saveza predstavlja danas glavnu trasu odakle kreće ilegalni transport radioaktivnih materijala iz hiljada skladišta koja su se preko noći našla van kontrole sovjetske centralne vlasti. U eri transacionalnih militarističkih organizacija poput Hezbolaha, Alefa ili Al Kaide, koje nemaju odgovornost za određenu teritoriju i stanovništvo, širenje OMU postaje ogromna bezbednosna pretnja. Američka autorka Džesika Stern daje obuhvatnu analizu opasnosti od terorista opremljenim OMU i prezentuje sisteme kako preduprediti ove pretnje. ${ }^{6}$ Ističe se potreba za preventivnim delovanjem kroz timove „na prvoj liniji fronta“, kao što su policijske snage, medicinsko osoblje, vatrogasne službe i sl. Danas vlada konsenzus među ekspertima za bezbednost da je problem širenja OMU neraskidiv sa problemom terorističkih grupa, naročito onih baziranih na religijskom

${ }^{5}$ Dragan Petrović i Bogdan Stojanović, Ravnoteža nuklearne moći SAD i Rusije (SSSR), op. cit., str. 148.

${ }^{6}$ Više o tome u: Jessica Stern, The Ultimate Terorists, Harvard University Press, 1999. 
fundamentalizmu. ${ }^{7}$ EU je takođe potencijalna meta napada, a o tome govore brojni uspeli i neuspeli pokušaji terorističkih akata u evropskim gradovima.

Empirijski pokazatelji govore da je teritorija Evropske unije „oaza mira“, za razliku od drugih svetskih regiona gde i dalje bujaju tradicionalni oružani konflikti. Čini se da je EU prevazišla problem tradicionalnih ratova koji više nisu prvorazredna pretnja evropskom miru, ali je njena teritorija potencijalna meta napada oružjem za masovno uništenje od strane privatnih grupa. EU ima 446 miliona stanovnika, što je posle Kine i Indije najveći broj ljudi na zaokruženoj državnoj teritoriji, iako za EU ne možemo reći da je država u pravom smislu reči. ${ }^{8}$ Evropska unija je od usvajanja popularno nazivanog Lisabonskog sporazuma koji ukida podelu na "stubove", a u oblasti Zajedničke spoljne i bezbednosne politike (eng. Common Foreign and Security Policy - CFSP) preuzela gotovo sve odredbe iz propalog Ugovora o Ustavu za Evropu. EU ima status pravnog lica, čime se ostvario nužan preduslov za efikasno sprovođenje bezbednosno-odbrambene politike u okviru CFSP. ${ }^{9}$ EU može da zaključuje međunarodne ugovore i bude član međunarodnih organizacija što je od suštinske važnosti u prevenciji širenja nuklearnog naoružanja i drugih vrsta oružja za masovno uništenje. Zaključak je da se $u$ ovom kontekstu može govoriti o zajedničkom nastupu EU na zaokruženoj teritoriji, poput državne u klasičnom smislu reči.

\section{Strategija EU protiv širenja oružja za masovno uništenje}

Evropska strategija bezbednosti (eng. European Security Strategy - ESS), koju je Evropski Savet usvojio u decembru 2003. godine, prepoznaje proliferaciju oružja za masovno uništenje kao jedan od pet glavnih izazova međunarodnoj bezbednosti. ${ }^{10}$ Proliferacija OMU predstavlja potencijalno najveću pretnju bezbednosti jer raste mogućnost trke u naoružanju, a napredak u biološkim naukama povećao je opasnost od biološkog oružja. ${ }^{11}$

\footnotetext{
${ }^{7}$ Videti: Richard Jackson, Nuclear biological, and chemical defense in the 21 st. Century, US Army War College Center for Strategic Leadership, Carlisle, PA, 1994.

8 "Size and population, European Union", Internet, https://europa.eu/europeanunion/about-eu/figures/living_en, 11/1/2020.

${ }^{9}$ Sastoji se od dva ugovora: Ugovor o EU i Ugovor o funkcionisanju EU. Više o suštini ugovora u: Dejana Vukčević, Bezbednost $i$ Evropska unija, Institut za političke studije, Beograd, 2008, str. 131.

${ }^{10}$ Pored proliferacije, tu su još: terorizam, regionalni konflikti, propadanje države i organizovani kriminal. Evidentno je da su ovi izazovi međusobno povezani i da je problem proliferacije u sprezi sa propadanjem države, organizovanim kriminalom, terorizmom i regionalnim konfliktima. Videti: "European Security Strategy", European Council, Brussels, 12 December 2003, pp. 3-5, Internet, http://consilium.europa.eu/ uedocs/cmsUpload/78367.pdf, 12/3/2020.
}

$26{ }^{11}$ Ibid., pp. 3-4. 
U isto vreme kad je usvojena Evropska strategija bezbednosti, Evropski savet je usvojio i Strategiju protiv širenja oružja za masovno uništenje (dalje: Strategija OMU) koja je u potpunosti posvećena problemu proliferacije OMU. Strategija OMU definiše aktivnosti Evropske unije na tri osnovna principa: efektivni multilateralizam, prevencija i saradnja. U uvodnom delu Strategije OMU predviđa se da će EU koristiti „,sve instrumente i politike koje su joj na raspolaganju“ kako bi se programi širenja kataklizmičnog oružja "sprečili, odvratili, zaustavili i gde je moguće eliminisali“". ${ }^{12}$ Takođe, u uvodnom delu strategije napominje se sprega između terorizma i širenja OMU, kao i sredstava njihove isporuke. ${ }^{13}$

Može se reći da je neproliferacioni režim opšteprihvaćen $u$ međunarodnom sistemu, gde postoji zanemarljivo mali broj država koje mu se nisu povinovale. Sve države članice EU su pripadnice neproliferacionog režima ustrojenog Sporazumom o neširenju nuklearnog oružja (eng. The Treaty on the Non-Proliferation of Nuclear Weapons - NPT) iz 1968. godine. ${ }^{14}$ Jedine države koje su trenutno izvan ovog sporazuma i režima koji propisuje jesu: Indija, Pakistan, Izrael i Južni Sudan koji nikada nisu pristupili sporazumu i Severna Koreja koja ga je formalno napustila 2003. godine.

Rasprostranjenija proliferacija OMU uvećava rizik upotrebe ovog oružja od strane država (npr. rat između Irana i Iraka) ili od strane terorističkih grupa koje bi mogle sprovesti akcije ubijanja i razaranja. ${ }^{15}$ Poslednja upotreba OMU od strane terorista bila je 1995. godine kada je teroristička religijska sekta Aum Šinrikjo (od 2000. godine poznata pod imenom Alef) izvršila napad nervnim gasom sarinom u tokijskom metrou, kada je poginulo 12, a ranjeno više hiljada ljudi. ${ }^{16}$ Posebnu brigu predstavlja širenje hemijskog naoružanja jer je know-how, materijale i opremu moguće nabaviti u druge svrhe. Hemijske proizvode, od kojih se neki lako mogu modifikovati u oružje, svakodnevno koristimo. Takođe, neki biološki agensi, kao i nuklearna tehnologija spadaju u tzv. dual use kategorije jer su istovremeno upotrebljive u civilnom i vojnom sektoru. Militarizacija civilnih nuklearnih programa ili ovih agenasa predstavlja dodatnu opasnost zbog toga što državni i

12 "EU Strategy against the Proliferation of Weapons of Mass Destruction", European Council, Brussels, 12 December 2003, p. 1, Internet, https:/ / www.nonproliferation.eu/ hcoc/wp-hcoc/uploads/EU-Strategy-Against-the-Proliferation-of-WMD-2003.pdf, 4/42020.

${ }^{13}$ Ibid.

${ }^{14}$ Za pun tekst ugovora videti: "Treaty on the Non-Proliferation of Nuclear Weapons", United Nations, 1968, Internet, https:/ /www.un.org/disarmament/wmd/nuclear/ npt/, 26/4/2020.

${ }^{15}$ Ibid., p. 2.

${ }^{16}$ Kenneth Pletcher, "Tokyo subway attack of 1995", March 13, 2020, Internet, https:/ /www.britannica.com/event/Tokyo-subway-attack-of-1995, 15/3/2020. 
nedržavni akteri mogu doći u posed ovih materijala pod drugim izgovorima. Oko $1 \mathrm{~kg}$ botulinskog toksina, uz efikasno sredstvo isporuke i stoprocentnu efikasnost, bilo bi sposobno da ubije čitavu ljudsku populaciju na planeti. ${ }^{17}$ Ipak, nemoguće je i nesvrsishodno zabraniti proizvodnju i držanje botulinskog toksina koji ima značaj u medicini i kozmetologiji. Problem dualnih upotreba koje je Evropska unija prepoznala u svojoj strategiji, predstavlja suštinsku prepreku sprečavanju širenja OMU. Tri su osnovna principa na kojima počiva strategija EU.

\section{Efektivni multilateralizam}

Prvi princip na kome se bazira Strategija OMU jeste efektioni multilateralizam. On znači da EU ne može samostalno ostvariti proklamovane ciljeve. EU agituje za vezivanje i poštovanje multilateralnih sporazuma i konvencija od strane svih država. Neproliferacione norme moraju biti zastupljene u ukupnim politikama svih država i da predstavljaju smernice spoljnopolitičkog delovanja. EU je posvećena sprovođenju i univerzalizaciji Sporazuma o neširenju nuklearnog naoružanja (NPT), Dodatnog protokola o inspekciji Međunarodne agencije za atomsku energiju (eng. International Atomic Energy Agency - IAEA), Konvencije o hemijskom naoružanju (eng. Chemical Weapons Convention - CWC), Konvencije o biološkom naoružanju (eng. Biological Weapons Convention - BTWC), Haškog kodeksa protiv širenja balističkih raketa (eng. Hague Code of Conduct Against Ballistic Missile Proliferation - HCOC), što ranije stupanje na snagu Sporazuma o sveobuhvatnoj zabrani nuklearnih testova (eng. Comprehensive Nuclear-TestBan Treaty - CTBT) i osnivanje organizacije koja bi pratila implementaciju. ${ }^{18}$ U EU se navodi da je potrebno poboljšati sposobnosti detekcije kršenja navedenih prohibitivnih normi i ojačati sistem sankcionisanja, sa Savetom bezbednosti UN kao finalnim arbitrom u skladu sa Glavom VII Povelje UN. ${ }^{19}$ Upotreba sile je mera ultima ratio za kojom bi trebalo posegnuti u poslednjoj instanci, uz centralnu ulogu Saveta bezbednosti. EU ispravno zaključuje da su postojeći međunarodni verifikacioni mehanizmi loši i nedovoljni, pa je potrebno uvođenje dodatnih verifikacionih instrumenata sa dozvoljenom iznenadnom kontrolom svih objekata i postrojenja u vezi sa OMU. EU izričito ističe da je spremna da pojača svoju političku, tehničku i finansijsku podršku agencijama zaduženim za verifikaciju. ${ }^{20}$ Osim sistema verifikacije, EU predviđa jačanje sistema izvoznih kontrola na taj način što bi trebalo razviti

${ }^{17}$ Dragan Petrović i Bogdan Stojanović, Ravnoteža nuklearne moći SAD i Rusije (SSSR), op. cit., str. 50.

18 "EU Strategy against the Proliferation of Weapons of Mass Destruction", op. cit., p. 5. ${ }^{19}$ Ibid.

$28{ }^{20}$ Ibid. 
kvalitetnije kriterijume, posebno za države koje su izvan postojećeg režima neproliferacije. ${ }^{21}$ Savet bezbednosti UN je 28. aprila 2004. godine jednoglasno usvojio Rezoluciju 1540 kao prvi međunarodni dokument koji se sveobuhvatno odnosi na sprečavanje širenja OMU i njihovih sredstava isporuke. Rezolucija 1540 je konvergentna Strategiji EU protiv širenja oružja za masovno uništenje jer percipira proliferaciju OMU kao glavnu pretnju međunarodnoj bezbednosti, utvrđuje globalni pristup problemu, što znači da je u rešavanju istog neophodna saradnja i smatra da je nužna prevencija širenja kako se nedržavni akteri ne bi domogli oružja kojim mogu naneti nepopravljivu štetu svakoj državi. Prema ovoj rezoluciji, sve članice UN su obavezane da moraju sprovoditi efektivne mere protiv proliferacije nuklearnog, hemijskog i biološkog oružja, kao i sistema njihove isporuke. ${ }^{22}$

Prema Rezoluciji 1540 postoje tri osnovne obaveze kojih se moraju pridržavati sve države članice UN. Prvo, zabranjena je podrška nedržavnim akterima koji teže posedovanju OMU i sredstava isporuke. Drugo, neophodno je usvajanje efektivnih zakonskih zabrana aktivnosti koje bi dovele do sticanja OMU i sredstava isporuke od strane nedržavnih aktera. Treće, potrebno je sprovođenje efikasnih mera smanjenja ranjivosti legitimnih aktivnosti koje mogu biti zloupotrebljene u cilju proliferacije OMU na nedržavne aktere. ${ }^{23} \mathrm{U}$ skladu sa ovom rezolucijom, kao pomoćno telo Saveta bezbednosti UN, osnovan je komitet poznat kao Komitet 1540 čiji je zadatak da prati i ojačava primenu rezolucije. Mandat ovog Komiteta 1540 produžavan je nekoliko puta rezolucijama Saveta bezbednosti, ali su mu svakom novom rezolucijom unapređene funkcije. ${ }^{24}$ Ovo telo trenutno ima mandat do 25. aprila 2021. godine. ${ }^{25}$ Sve članice su obavezane da Komitetu 1540 podnose izveštaj o preduzetim merama u skladu sa rezolucijom. Evropska unija je velika podrška radu ovog Komiteta, ali i sprovođenju Rezolucije 1540. Kancelarija UN za poslove razoružanja sprovodi projekte Evropske unije predviđene u zajedničkim akcijama Saveta EU. Evropska unija je bila sufinansijer nekoliko regionalnih seminara održanih u cilju unapređenja implementacije Rezolucije $1540 .{ }^{26}$ Posvećenost Evropske unije doslednoj primeni Rezolucije 1540 je evidentna jer (uz SAD) EU predstavlja

\footnotetext{
${ }^{21}$ Ibid.

22 “Resolution 1540", UN Security Council, 28 April 2004, Internet, https:/ / www.un.org/ ga/search/view_doc.asp?symbol=S/RES/1540\%20(2004), 6/5/2020.

${ }^{23}$ Ibid.

${ }^{24} 1540$ Committee, UN Security Council Committee established pursuant to resolution 1540, Internet, https://www.un.org/en/sc/1540/about-1540-committee/generalinformation.shtml, 11.4.2020.

${ }^{25}$ Ibid.

26 “The European Union Strategy against Proliferation of Weapons of Mass Destruction: effective multilateralism, prevention and international cooperation", op. cit., p. 16.
} 
najznačajniji oslonac za njeno adekvatno sprovođenje. IAEA je osnovana 1957. godine s ciljem da promoviše miroljubivu upotrebu nuklearne energije, a od potpisivanja Sporazuma o neširenju nuklearnog naoružanja igra ulogu "glavnog inspektora“ za njegovo kršenje. Ciljevi IAEA su konvergentni onima iz strategije EU, a oni se sprovode kroz mehanizme kontrole, odgovornosti i zaštitu nuklearnog i drugih radioaktivnih materijala. Evropska unija je najveći donator fondu za nuklearnu bezbednost Međunarodne agencije za atomsku energiju. ${ }^{27}$ Osim finansijske, EU pruža i političku podršku agenciji. EU promoviše univerzalizaciju multilateralnih sporazuma o neproliferaciji, uključujući Dodatni protokol i sporazume o inspektorima, jača kapacitete država za detekciju i odgovor na ilegalnu trgovinu nuklearnih materija, i deli informacije do kojih dođe unapređujući fond znanja agencije. Takođe, pomaže u zaštiti i transferu osetljivih materijala i opreme. Od 2003. godine do danas EU je finansirala brojne projekte koje je sprovodila $I A E A$. Tu su projekti obezbeđivanja nuklearnih materijala koji se skladište i koriste u nuklearnim postrojenjima, kao i projekti transporta tih materijala koje je IAEA uspešno sprovela uz pomoć Evropske unije. ${ }^{28}$

Program saradnje Evropske komisije i Međunarodne agencije za atomsku energiju u inspekciji nuklearnih postrojenja otpočeo je još davne 1981. godine. Ovim programom rukovodi Zajednički istraživački centar (eng. Joint Research Centre - JRC), generalni direktorat Evropske komisije. IAEA od instituta pod ingerencijom JRC dobija podršku kroz ekspertizu, tehnološku pomoć, obuku inspektora, nuklearnih forenzičara, pomoć u upravljanju otpadom i dr. ${ }^{29}$ Inspektori Evropske zajednice za atomsku energiju (eng. European Atomic Energy Community - Euratom) deluju kao regionalni mehanizam kontrole nuklearne opasnosti. ${ }^{30} J R C$ je dao jedinstven doprinos $\mathrm{u}$ prevenciji i otkrivanju ilegalne trgovine nuklearnim materijalima kroz inventivni i trenutno najsavremeniji metod analize oduzetog materijala jer su rezultati mogući već nakon 24 časa. ${ }^{31}$ Ovom metodom JRC je u stanju da za kratko vreme otkrije sa velikom preciznošću poreklo i potencijalnu rutu kretanja zaplenjenog materijala, što daje mogućnost za brzu reakciju policije i bezbednosnih službi. EU agituje za globalnu implementaciju bezbednosnih standarda koje predlažu eksperti iz IAEA i služi kao čuvar propisanih normi. Osim toga, EU konstantno promoviše miroljubivu upotrebu nuklearne

\footnotetext{
${ }^{27}$ Ibid., p. 19.

${ }^{28}$ Transport opasnih materijala IAEA je sprovela pomoću EU u: Libiji, Egiptu, Rumuniji, Bugarskoj, Srbiji itd. Ibid., p. 21.

29 "Peaceful uses of nuclear technology", General Secretariat of the Council, publications 049/2012, Brussels, April 2012, p. 1.

${ }^{30}$ Ibid.

31 "The European Union Strategy against Proliferation of Weapons of Mass Destruction:

30 effective multilateralism, prevention and international cooperation", op. cit., p. 25.
} 
energije i ističe neophodnost koordinacije sa inspektorima IAEA u svim zemljama gde postoje nuklearni reaktori. EU pomaže Međunarodnoj agenciji za atomsku energiju, prosečno sa 150 miliona evra godišnje, što je čini drugim najvećim donorom posle SAD. ${ }^{32}$

Sporazum o sveobuhvatnoj zabrani nuklearnih proba usvojen je na zasedanju Generalne skupštine UN 1996. godine, ali do danas nije stupio na snagu jer ga nisu ratifikovale sve države koje poseduju nuklearnu tehnologiju iz Aneksa 2 ovog ugovora. ${ }^{33}$ Sporazum zabranjuje sve nuklearne probe (u atmosferi, pod vodom, na površini, ispod površine). CTBT predviđa stvaranje međunarodne organizacije koja će se starati od sprovođenju sporazuma, a koja ne može biti formirana sve dok sporazum ne stupi na snagu. U toj fazi, EU igra veoma zapaženu ulogu jer pomaže u pripremi buduće organizacije koja će služiti kao sistem verifikacije sporazuma. Mehanizam monitoringa obuhvatiće preko 300 tehnoloških centara iz kojih će se vršiti kontrola nuklearnih testova na čitavoj planeti. EU je finansirala nekoliko krucijalnih projekata u pripremi buduće organizacije. Prvo, razvoj ljudskih kapaciteta kroz kompjuterske obuke od važnosti za ekspertizu. Drugi projekat EU se odnosi na unapređenje znanja i modusa prepoznavanja plemenitih gasova, čije prepoznavanje predstavlja suštinski element za detekciju podzemnih i podvodnih nuklearnih eksplozija. Treći projekat se tiče podrške na licu mesta putem operativne podrške, logistike i prevoza opreme. Takođe, EU sprovodi projekat pružanje tehničke pomoći afričkim državama potpisnicama zbog posebno slabe finansijske situacije u pojedinim afričkim zemljama. ${ }^{34}$

Konvencija o hemijskom naoružanju predstavlja fundamentalni okvir borbe protiv širenja OMU i okosnicu režima neproliferacije. Konvencija je stupila na snagu 29. aprila 1997. godine, a njenu suštinu čine odredbe o zabrani razvoja, proizvodnje, skladištenja, trgovine i naravno upotrebe hemijskog naoružanja. Prema podacima Organizacije za zabranu hemijskog naoružanja (formirana konvencijom), do sada je uništeno oko $80 \%$ ukupnog hemijskog naoružanja na planeti, što nam govori da i dalje postoje ogromne zalihe tog oružja. ${ }^{35}$ Evropska unija pruža finansijsku pomoć Organizaciji za zabranu hemijskog naoružanja, promoviše univerzalnost konvencije kao norme koje se sve države moraju pridržavati, organizuje regionalne

32 "Peaceful uses of nuclear technology", op. cit., p. 2.

${ }^{33}$ Videti: "Comprehensive Nuclear-Test-Ban Treaty", General Assembly of the United Nations, Resolution 50/245, NY, 17 September 1996, Internet, http:/ / www.ctbto.org/ fileadmin/content/treaty/treaty_text.pdf, 6/5/2020.

34 "The European Union Strategy against Proliferation of Weapons of Mass Destruction: effective multilateralism, prevention and international cooperation", op. cit., p. 34.

35 "Committed to complete and verifiable destruction", OPCW, Internet, http:// www.opcw.org/our-work/demilitarisation/, 6/5/2020. 
radionice i treninge, osniva analitičke laboratorije, zalaže se i razvija projekte miroljubive upotrebe $\mathrm{u}$ hemijskoj industriji. Na taj način ona značajno doprinosi sprečavanju širenja hemijskog naoružanja. ${ }^{36}$

Konvencija o biološkom i toksičnom oružju je prvi multilateralni ugovor koji zabranjuje u potpunosti određenu kategoriju naoružanja. Stupio je na snagu 1975. godine dopunjujući postojeći Ženevski protokol iz 1925. godine. ${ }^{37}$ Mana konvencije je u tome što nije stvorila verifikacioni instrument ili neku vrstu nadzorne organizacije koja bi se starala o implementaciji. Za nuklearno naoružanje to je IAEA, za hemijsko Organizacija za zabranu hemijskog naoružanja, dok za biološko oružje ne postoji ništa slično. Doprinos EU na ovom polju sličan je aktivnostima u sferi zabrane hemijskog oružja i svodi se na isticanje univerzalnosti Konvencije, finansiranje projekata, regionalnih treninga i radionica, kao i finansijsko-tehničku podršku nacionalnim implementacionim mehanizmima u razvoju režima zabrane i kontrole uvozno-izvoznih roba.

\section{Prevencija širenja osetljivih materijala i tehnologija}

Drugi bazični princip se odnosi na prevenciju kroz univerzalizaciju multilateralnih instrumenata koji nameću prohibiciju širenja, jačanje sprovođenja preuzetih obaveza kroz tehničko-finansijsku pomoć, jačanje kontrole izvoza kako u članicama EU tako i partnerskim državama, stručnu pomoć pri demontiranju postojećih arsenala OMU, preusmeravanje naučnika sa vojnih na miroljubive programe i jačanje nacionalnih kapaciteta za sprečavanje ilegalne trgovine materijalima i znanjima $u$ vezi sa OMU. ${ }^{38}$ Evropska komisija ima status posmatrača u Grupi nuklearnih dobavljača (eng. Nuclear Suppliers Group), osnovanoj 1974. godine kao odgovor na indijski nuklearni test koji je pokazao da je moguće preći sa civilnog na vojni nuklearni program.${ }^{39}$ Grupa je napravila listu dobara koja se mogu izvesti nenuklearnim državama samo uz odobrenje inspektora IAEA. Međutim, vrlo je teško sprečiti

36 "The European Union Strategy against Proliferation of Weapons of Mass Destruction: effective multilateralism, prevention and international cooperation", op. cit., pp. 37-38.

${ }^{37}$ The Biological Weapons Convention, UN Office for Disarmament Affairs, Internet, https://www.un.org/disarmament/wmd/bio/, 7/5/2020.

38 "The European Union Strategy against Proliferation of Weapons of Mass Destruction: effective multilateralism, prevention and international cooperation", General Secretariat of the Council, brochure, Brussels, November 2008, pp. 10-11.

${ }^{39}$ Poslednje plenarno zasedanje Grupe nuklearnih dobavljača bilo je u junu 2019. godine u Kazahstanu. Grupa ima 48 država članica. Videti: "Public Statement of the 2019 NSG Plenary - Nur-Sultan", Kazakhstan, Internet, https://www.nuclearsuppliers group.org/en/news/246-public-statement-of-the-2019-nsg-plenary-nur-sultan32 kazakhstan, 1/4/2020. 
ilegalnu distribuciju dobara, a naročito nuklearne ekspertize. Znanje se ne može kontrolisati, sprečiti ili uništiti, ali je kontrolu izvora materijala i postrojenja neophodnih za pravljenje nuklearne bombe (rudnici uranijuma, nuklearni reaktori, postrojenja za testiranje i sl.) moguće ostvariti. Osim permanentne fluktuacije informacija i znanja, otežavajuću okolnost u sprečavanju ilegalne trgovine predstavlja pomenuti problem dualne upotrebe. Sve navedeno sprečava da se neki od proklamovanih ciljeva EU iz Strategije OMU ostvare u potpunosti, ali je napredak ka njihovom ostvarenju svakako uočljiv.

\section{Saradnja sa partnerima}

Treći princip se odnosi na direktnu saradnju sa partnerima, gde se SAD navode kao ključni partner, a potom slede Rusija, Japan i Kanada. ${ }^{40}$ Osim saradnje sa državama, ističe se i saradnja sa UN, NATO i drugim međunarodnim organizacijama i institucijama. Dijalog sa industrijskim prvacima je takođe od velike važnosti, i tu se navodi prvobitno evropska a potom i saradnja sa američkom industrijom (posebno u biološkom sektoru). ${ }^{41}$ EU je već mnogo učinila $u$ domenu kontrole nad patogenim mikroorganizmima i toksinima, kako u državama članicama tako i zemljama koje su u procesu pristupanja. Evropska unija utiče na jačanje evropskog i nacionalnih zakonodavstava u domenu kontrole bioloških pretnji, a još 2005. godine je kao nezavisnu agenciju kreirala Evropski centar za prevenciju i kontrolu bolesti (eng. European Centre for Disease Prevention and Control $E(D C)$, s ciljem da identifikuje i proceni pretnje po zdravlje ljudi koje dolaze od zaraznih bolesti. ${ }^{42}$ Problem fukcionisanja u praksi bio je vidljv nakon pandemije korona virusa 2020. godine, gde je nadnacionalni nivo prevencije širenja bolesti zakazao, pa je čitav posao pao na „leđa“ država članica. Ipak, ECDC ima veliki značaj u prikupljanju informacija o dometu, snazi i opasnosti zaraze koja je uglavnom uvek transnacionalnog karaktera.

Strategija protiv proliferacije OMU koju je Evropska unija usvojila, iako poseduje manjkavosti jer često gubi dodir sa realnom situacijom na terenu, ima snažan uticaj na ublažavanje pretnje širenja OMU stvarajući čvrst normativni okvir globalnog dometa. EU je shvatila da su potrebna politička rešenja za bezbednosne probleme. To znači da je potrebno urazumiti države da im OMU nije potrebno. Što se država oseća bezbednije, veća je verovatnoća da će odustati od programa naoružavanja. ${ }^{43} \mathrm{U}$ tom smislu EU

40 "EU Strategy against the Proliferation of Weapons of Mass Destruction", op. cit., p. 7. ${ }^{41}$ Ibid., p. 11.

${ }^{42}$ Videti: European Centre for Disease Prevention and Control, An Agency of the European Union, Internet, http://www.ecdc.europa.eu/en/aboutus/Pages/About Us.aspx, 2/4/2020.

43 "EU Strategy against the Proliferation of Weapons of Mass Destruction", op. cit., p. 6. 
će podsticati regionalne bezbednosne sporazume i regionalnu kontrolu naoružanja. ${ }^{44}$ Evropska unija je tako utvrdila dva glavna pravca rešavanja problema proliferacije. Prvo - da je potrebno tražiti politička rešenja (uz bezbednosne garancije) za strahove i ambicije država koji prouzrokuju njihovu težnju za posedovanjem OMU. Politička rešenja, međutim, nije moguće postići u kratkom roku, o čemu najbolje svedoče višedecenijski problemi poput permanentne nestabilnosti na Bliskom istoku, problema iranskog nuklearnog programa, tenzije na Korejskom poluostrvu ili sukoba na relaciji Indija-Pakistan. Drugo - pitanje sprečavanja širenja OMU zahteva globalni pristup, ali se rešenja moraju tražiti prvobitno $u$ regionalnim aranžmanima. EU je razvila potrebne unutrašnje strukture, zadužene za adekvatno sprovođenje Strategije OMU: debate u Savetu na svakih šest meseci o efektivnosti sprovođenja i osnivanje Monitoring centra zaduženog isključivo za nadgledanje implementacije odredbi Stretegije OMU.

\section{Klauzula o neširenju i monitoring centar}

Savet EU je novembra 2003. godine usvojio klauzulu o neširenju oružja za masovno uništenje (dalje: klauzula OMU), kao sredstvo promovisanja neširenja OMU.$^{45}$ Namera je bila da klauzula bude uključena kao suštinski element svih novih, obnovljenih ili revidiranih mešovitih sporazuma, koje EU sklapa sa trećim državama (nečlanicama EU). Neki eksperti u Evropskom parlamentu dovode $\mathrm{u}$ pitanje efektivnost ove klauzule kao sredstva sprečavanja širenja OMU zbog nedovoljne posvećenosti pojedinih država članica koje ekonomski interes stavljaju iznad bezbednosnog elementa na kome insistira klauzula. ${ }^{46}$

EU je i pre usvajanja teksta klauzule bila aktivna na projektima neproliferacije, i to u Rusiji kroz Nan-Lugarov program Zajedničke redukcije pretnji (eng. Cooperative Threat Reduction - CTR) ${ }^{47}$ i Organizaciju za energetski razvoj Korejskog poluostrva (eng. Korean Peninsula Energy Development Organization - KEDO). ${ }^{48}$ EU se posvetila problemu proliferacije OMU zbog

${ }^{44}$ Ibid.

45 "Mainstriming non-proliferation policies into the EU's wider relations with third countries", Council of the European Union, no. 14997/03, Brussels, 19 November 2003, http:/ / www.sussex.ac.uk/Units/spru/hsp/documents/2003-1117\%20Mainstreaming.pdf, Internet, 6/2/2020.

${ }^{46}$ Lina Grip, "The EU Non-Proliferation Clause: A Preliminary Assessment", Background Paper, SIPRI, November 2009, p. 1.

${ }^{47}$ Videti: Richard Lugar, "Cooperative Threat Reduction and Nuclear Security", Georgetown Journal of International Affairs, Vol. 10, No. 1, 2009, pp. 183-189.

${ }^{48}$ Agreement on the Establishment of the Korean Peninsula Energy Development Organization, 9th March 1995, Internet, http://www.kedo.org/pdfs/Establishment

34 KEDO.pdf, 20/3/2020. 
opasnosti od eventualnog napada nedržavnih aktera, ali i zbog širenja njenog članstva. Naime, te godine kada su usvojene Evropska strategija bezbednosti, Strategija OMU i klauzula o neširenju, ugovor o pristupanju EU potpisalo je deset zemalja i očekivao se veliki talas proširenja. Stoga je EU želela da razvije koherentan i integrativni pristup problemu proliferacije, jer su u njeno članstvo ulazile nove države sa različitim bezbednosnim kulturama, kapacitetima i rutinama. Međutim, američka invazija na Irak 2003. godine pokazala je da unutar same EU postoje brojna mimoilaženja u stavovima koji se tiču bezbednosne problematike na polju OMU. Možemo postaviti pitanje - šta bi bilo da je OMU u Iraku zaista pronađeno, jer su zvanični izveštaji pre invazije (frizirani ili ne) govorili u prilog tezi da Irak to oružje poseduje? Da li bi se onda tolerisala pasivnost pojedinih članica EU prilikom invazije na Irak? Politika proširenja je čvrsto povezana sa politikom neproliferacije, jer EU putem klauzule OMU uslovljava sve potencijalne članice, ali i sve druge sa kojima potpisuje mešovite ugovore da poštuju i pridržavaju se neproliferacionih normi.

Uspostavljanje zajedničkog i koherentnog pristupa problemu proliferacije, prva je predložila Švedska. ${ }^{49}$ Tadašnja ministarka spoljnih poslova Švedske, Ana Lind, pokrenula je aprila 2003. inicijativu za donošenje strategije za borbu protiv širenja OMU. Na toj bazi sredinom iste godine usvojena su dva dokumenta koja su prethodila i utrla put prethodno analiziranoj Strategiji OMU, a to su: Osnovni principi za EU strategiju protiv širenja OMU i Akcioni plan za implementaciju osnovnih principa. „EU će razmotriti uvođenje efikasnu politiku štapa $i$ šargarepe, povezanu sa obavezama neširenja u odnosu sa trećim zemljama. To će biti urađeno posebno u kontekstu sporazuma o saradnji ili programa pomoći. Relevantne radne grupe će imati zadatak da preispitaju politiku EU prema pojedinim državama." ${ }^{50}$ Od novembra 2003. godine, kada je Savet usvojio tekst klauzule OMU, stav prema neširenju OMU predstavlja fundamentalan element za EU kada razmatra odluku o ulasku u pregovore i sporazume sa trećim državama. Umetanjem OMU klauzule u mešovite sporazume, moguće je usloviti trgovinski vid saradnje (koji je pod kompetencijom Zajednice) obavezom prihvatanja klauzule o neproliferaciji (koja je u domenu CFSP). Za razliku od sporazuma Zajednice sa trećim državama (koje može usvojiti Savet EU većinom), mešoviti sporazumi zahtevaju konsenzus u Savetu i moraju biti potpisani i ratifikovani od strane svih članica EU pre nego što stupe na snagu, jer osim ekonomskog sadrže i političke elemente. Klauzula OMU je urađena po uzoru

${ }^{49}$ A. J. K. Bailes, “The European Security Strategy: An Evolutionary History”, Policy Paper, No. 10, SIPRI, Stockholm, 2005, p. 10.

50 "Action Plan for the Implementation of the Basic Principles for an EU Strategy against Proliferation of Weapons of Mass Destruction", Council of the European Union, 10354/1/03, Brussels, 13 June 2003, p. 6, Internet, http://www.sussex.ac.uk/Units /spru/hsp/documents/2003-0616\%20Action\%20plan.pdf, 22/4/2020. 
na klauzulu o ljudskim pravima (human rights clause) koja je promovisana 90-ih godina u mešovitim ugovorima sa trećim državama. ${ }^{51}$

Suština klauzule OMU je sadržana u tome da su ,strane saglasne da proliferacija OMU i njihovih sredstava isporuke, od strane državnih i nedržavnih aktera, predstavlja najozbiljniju pretnju međunarodnoj stabilnosti i bezbednosti". ${ }^{2}$ "Strane su prema tome saglasne da sarađuju $i$ doprinose borbi protiv proliferacije OMU i sredstava isporuke kroz puno pridržavanje i sprovođenje preuzetih obaveza iz sporazuma o razoružanju i neproliferaciji. Strane su saglasne da ova odbredba predstavlja suštinski element ovog sporazuma". ${ }^{53} \mathrm{U}$ drugom delu klauzule kaže se da će „strane sarađivati i doprinositi borbi protiv širenja OMU i sredstava isporuke: preduzimanjem koraka kao što su potpisivanje, ratifikacija ili pristupanje svim relevantnim međunarodnim instrumenatima i njihovo puno sprovođenje; uspostavljanjem efektivnog sistema izvozne kontrole na nacionalnom nivou, kontrolom izvoza i tranzita dobara u vezi sa OMU, uključujući i dualne tehnologije, i da će biti sprovedene efektivne sankcije za kršenje tih kontrola" ${ }^{54}$

Vidi se da klauzula $u$ prvom delu ističe potrebu pridržavanja svih preuzetih obaveza po pitanju neširenja OMU, kao i implicitnu pretnju da će neispunjenje tih obaveza voditi suspenziji sporazuma EU sa tom državom. U drugom delu klauzule predviđa se potreba za dodatnim obavezivanjem druge strane (ukoliko država nije pristupila nekom od postojećih međunarodnih aranžmana), ali je ovaj deo klauzule fakultativnog ili suštinskog karaktera od slučaja do slučaja. Klauzula OMU predstavlja kvalitetan instrument u borbi protiv širenja oružja za masovno uništenje, jer istovremeno sadrži potreban mehanizam štapa i šargarepe. Predviđene su sankcije, a najoštrija je suspenzija sporazuma. Time se uslovljava druga strana (koja ima šta da izgubi), da ima obavezu prihvatanja i sprovođenja normi i mera protiv širenja OMU. Međutim, postoje brojne kritike ove klauzule iz same EU zbog nedoumica kakvu bi formu klauzula trebalo da ima u sporazumima sa različitim trećim državama, jer nisu sve podjednako posvećene borbi protiv neširenja OMU. Osim toga, kako se boriti protiv otpora klauzuli u državama koje su vrlo problematične kada je u pitanju proliferacija (npr. sporazum EU sa Indijom). Decembra 2008. Savet EU formulisao je tzv. „Nove smernice za delovanje EU u borbi protiv širenja OMU“, gde se jedan deo bavi „jačanjem diplomatskih instrumenata kroz bolje sprovođenje klauzule OMU“ ${ }^{55}$ "Nove smernice“ su

${ }^{51}$ Lina Grip, "The EU Non-Proliferation Clause: A Preliminary Assessment", op. cit., p. 3.

52 "Mainstriming non-proliferation policies into the EU's wider relations with third countries", Council of the European Union , op. cit., p. 4.

${ }^{53}$ Ibid.

${ }^{54}$ Ibid.

55 "Council conclusions and new lines for action by the European Union in combating proliferation of weapons of mass destruction and their delivery systems", Council of the European Union, 17172/08, Brussels, 17 December 2008, p. 22. 
zamišljene kao instrument uvećaja efektivnosti i uticaja EU u operacionalizaciji ideja o neširenju OMU. „Nove smernice“ nemaju nameru da zamene Strategiju OMU već da povećaju njenu efikasnost i obezbede bolje praktično sprovođenje. Svi sporazumi o stabilizaciji i pridruživanju imali su ovu klauzulu kao suštinski element, što znači da je ona nužan uslov za svaku buduću članicu EU. Za sada EU ostaje posvećena nužnom inkorporiranju ove klauzule u mešovitim sporazumima sa trećim državama. ${ }^{56} \mathrm{U}$ slučaju primene klauzule OMU postoje brojna otvorena pitanja, kao što su: da li sve članice EU imaju jednak interes kada je reč o proliferaciji; da li je EU spremna da blokira potpisivanje sporazuma koji su joj od velikog ekonomskog značaja u situacijama kada druga strana nije voljna da prihvati klauzulu OMU; kada je drugi deo klauzule koji se odnosi na dodatno pristupanje međunarodnim neproliferacionim aranžmanima suštinskog, a kada fakultativnog karaktera. Sva tri pitanja se odnose na problem ne-uniformnosti pristupa EU klauzuli u međunarodnim sporazumima. Pored manjkavosti koje nesumnjivo postoje, klauzula OMU predstavlja funkcionalan instrument EU u borbi protiv širenja oružja za masovno uništenje, a tako će i ostati sve dok postoji doslednost $u$ njenoj implementaciji.

Savet EU je 12. decembra 2006. godine osnovao Monitoring centar čije je osnivanje tri godine ranije predvidela Strategija OMU. ${ }^{57}$ Cilj ovog centra je monitoring nad implementacijom Strategije protiv širenja OMU. Donošenju odluke o osnivanju prethodili su teroristički napadi u Madridu (2004) i Londonu (2005) u kojima je ukupno stradalo oko 250, a ranjeno više hiljada ljudi. ${ }^{58}$ Da su kojim slučajem teroristi koristili OMU umesto konvencionalnog eksploziva, broj žrtava bi bio više stotina ili hiljada puta veći. Napadi su pokazali da postoji permanentna pretnja i da je potrebno što pre otelotvoriti odredbe iz Evropske strategije bezbednosti i Strategije protiv širenja OMU. Obim zadataka Monitoring centra koincidira sa delokrugom Strategije OMU. Tri principa iz strategije, takođe su osnovne smernice $u$ delovanju. Konkretna zaduženja Monitoring centra odnose se na: svakodnevno sprovođenje strategije, dalji razvoj strategije (npr. predlozi za njenu reviziju), obezbeđivanje koherentnosti programa pomoći (monitoring nad projektima) i kontakt sa

\footnotetext{
${ }^{56}$ Spisak svih ugovora $\mathrm{u}$ kojima je inkorporirana klauzula OMU: Inventory of Agreements Containing the Weapons of Mass Destruction Clause, Treaties Office database, G.AFFGEN. 3 Legal Affairs Division, Internet, https:/ / ec.europa.eu/world/ agreements/ClauseTreatiesPDFGeneratorAction.do?clauseID=28, 18.4.2020.

${ }^{57}$ Videti: "EU Strategy against the Proliferation of WMD: monitoring and enhancing consistent implementation", Council of the European Union, concept paper, no. 16694/06, Brussels, 12 December 2006, Internet, http:/ / register.consilium.europa.eu/ doc/srv?l=EN\&f=ST\%2016694\%202006\%20INIT, 15/4/2020.

${ }^{58}$ William Keller, "Anatomy of a Terrorist Attack: An in-Depth Investigation into the London and Madrid Subway Bombings of 2005 and 2004", working paper, Matthew B. Ridgway Center, University of Pittsburgh, 2006.
} 
trećim državama i organizacijama. ${ }^{59}$ Esencijalna je koordinacija Monitoring centra sa Centrom za obaveštajnu analitiku (eng. EU Intelligence Analysis Centre - EU INTCEN ${ }^{60}$, koji je od januara 2011. godine deo Evropske službe za spoljne poslove (eng. European External Action Service - EEAS), i sledstveno tome pod ingerencijom Visokog predstavnika za spoljnu i bezbednosnu politiku. ${ }^{61}$ Zadatak EU INTCEN je da pruža obaveštajne podatke Evropskoj službi za spoljne poslove i državama članicama, iz oblasti Zajedničke spoljne i bezbednosne politike i Zajedničke bezbednosne i odbrambene politike. ${ }^{62}$ Iako je EU SITCEN nastao 1999. godine kao ad hoc grupa analitičara koja vrši obradu podataka iz otvorenih izvora (tzv. open source intellegence), danas ovaj organ vrši klasifikaciju podataka poput državnih obaveštajnih službi i na dobrom je putu da postane respektabilna baza podataka. Monitoring centar takođe ostvaruje saradnju sa Evropskom komisijom i služi kao telo za koordinaciju između Saveta i Komisije. Monitoring centar prikuplja podatke ali taj posao u prvoj instanci radi EU INTCEN, dok Monitoring centar te podatke analizira i predlaže politike EU u domenu neproliferacije OMU. Takođe, Monitoring centar je u stalnoj vezi sa Koordinatorom za protiv-terorizam, kao i sa drugim odeljenjima Sekretarijata Saveta EU. ${ }^{63}$ Takođe, Visoki predstavnik za spoljnu i bezbednosnu politiku koji rukovodi EEAS, ima glavnog savetnika i specijalnog izaslanika za neproliferaciju i razoružanje koji je u stalnom kontaktu sa Monitoring centrom. ${ }^{64}$

\section{Doprinos EU u kriznim žarištima proliferacije}

Pitanje proliferacije nuklearnog oružja postaje prioritetna tema posle kraha Sovjetskog Saveza kada ogromne količine OMU ostaje relativno slabo kontrolisano dok se političko-ekonomski sistem nekadašnja supersile raspadao. Tokom 90-ih EU nije imala zajedničku strategiju rešavanja problema proliferacije jer se borila za unutrašnju koheziju i gradila sopstveni

59 "EU Strategy against the Proliferation of WMD: monitoring and enhancing consistent implementation", op. cit., p. 6.

${ }^{60}$ Do 2012. zvanični naziv ovog centra bio je EU Situation Centre - EU SITCEN, kada je preimenovan u EU INTCEN.

${ }^{61}$ European External Action Service, HQ Organizational chart, Internet, https:/ / eeas. europa.eu/sites/eeas/files/2020-01-05-eeas-2.0_orgchart.pdf, 12.4.2020.

62 "EU INTCEN", fact sheet, Internet, http://statewatch.org/news/2016/may/euintcen-factsheet.pdf, 10/2/2020.

63 "EU Strategy against the Proliferation of WMD: monitoring and enhancing consistent implementation", op. cit., p. 9.

${ }^{64}$ „Disarmament, Non-Proliferation and Arms Export Control”, European External Action Service, 8.8.2016., Internet, http://eeas.europa.eu/non-proliferation-and-

38 disarmament/special_envoy_en.htm, 11/4/2020. 
identitet na nadnacionalnom nivou. Prvi test za EU bile su: akvizicija nuklearnog oružja od strane Pakistana i reafirmacija Indije kao nuklearne sile, nuklearne aspiracije Severne Koreje, Irana, Iraka i Libije. EU je imala problem kreiranja zajedničkog sveobuhvatnog pristupa problemu proliferacije, koji je postojao sve do usvajanja pomenute strategije iz 2003. godine. EU je u pojedinim kriznim žarištima dala veliki doprinos smanjivanju rizika proliferacije, dok je na drugim mestima igrala zanemarljivu ulogu.

\section{Indija i Pakistan}

Indija je prvu nuklearnu detonaciju izvela u tzv. „miroljubive“ svrhe 1974. godine, ali se tenzija u južnoj Aziji razvija posebno od 1998. kada i Pakistan postaje nuklearna sila. Pregovori EU i Indije oko potpisivanja sporazuma o slobodnoj trgovini otpočeli su 2007. godine. Tada se pokazala manjkavost same klauzule OMU. Indija je jedna od zemalja koja poseduje nuklearno naoružanje, a pri tome nije potpisnik Sporazuma o neširenju nuklearnog oružja. Takođe, Indija nije ratifikovala Sporazum o sveobuhvatnoj zabrani nuklearnih testova. Osim toga, Indija ne pokazuje preteranu ambiciju da se posveti borbi protiv neširenja OMU i EU je vrlo teško mogla da je uslovi klauzulom OMU. Indija je odbila takvo uslovljavanje i pregovori o sporazumu o slobodnoj trgovini na relaciji EU-Indija su suspendovani 2013. godine. ${ }^{65}$ Ovakav pristup uzrokuje spekulacije o tome da bi se EU u određenim situacijama ekonomskih benefita mogla odreći klauzule OMU kao nužnog uslova za potpisivanje sporazuma o slobodnoj trgovini. Pregovori sa Indijom nisu propali zbog indijskog odbijanja klauzule OMU već zbog smanjene ambicije za ekonomsku saradnju. ${ }^{66} \mathrm{U}$ tom slučaju, stvorili bi se dvostruki standardi i izgubila bi se smisao čitave ideje o klauzuli OMU kao neophodnom uslovu za sve mešovite sporazume sa trećim zemljama. ${ }^{67}$ Ukoliko bi se u jednom slučaju napravio izuzetak, to bi značilo i kraj klauzule OMU koja je do sada inkorporirana u brojne mešovite sporazume.

Nuklearni testovi Indije i Pakistana iz maja 1998. godine unutar EU su razvile razmimoilaženja u pristupu. Nemačka, Danska i Švedska su zamrznule svoje programe pomoći dok su se ostale članice zadržale na retoričkoj osudi. Od samog početka ključnu ulogu u krizi igrale su SAD, dok se uloga EU svodila na podšku američkoj politici. Indija i Pakistan nisu potpisnice Sporazuma o neširenju nuklearnog oružja iako su de facto

${ }^{65}$ European Comission, Trade policy, https://ec.europa.eu/trade/policy/countries-andregions/countries/india/, Internet, 16.4.2020.

${ }^{66}$ Ibid.

67 "EU aide worried by calls to drop India WMD clause", Reuters, 2. March 2007, Internet, http://www.bilaterals.org/spip.php?article7311, 8/4/2020. 
nuklearne sile. SAD su 2005. napravile sporazum sa Indijom u cilju omogućavanja međusobne trgovine bez izričitih zahteva da se Indija odrekne svog nuklearnog arsenala. Članice EU su imale priliku unutar IAEA i Grupe nuklearnih dobavljača da blokiraju američko-indijski sporazum, ali je izostao zajednički pristup država članica koje su bile podeljene u stavu. ${ }^{68}$ Posle tri godine protivljenja Austrije i Irske, na snažne pritiske SAD, Ujedinjenog Kraljevstva i Francuske, sporazum je zaključen 2008. godine, čime je Indija izbegla sudbinu drugih država koje su bile pod snažnim sankcijama zbog akvizicije nuklearnog oružja. ${ }^{69}$ Slična situacija je i sa indijskim rivalom Pakistanom, na koji se istovremeno odnosilo neslaganje članica EU o tome da li bi trebalo kazniti tu državu zbog nuklearizacije. To se nije desilo i EU nije napravila značajan doprinos u indijsko-pakistanskom kriznom žarištu u kontekstu denuklearizacije, tj. sprečavanja širenja oružja za masovno uništenje.

\section{Severna Koreja}

Uz iranski nuklearni program, Severna Koreja čini jedan od dva najvažnija proliferaciona žarišta u XXI veku i stoga predstavlja izazov za zajedničku spoljnu i bezbednosnu politiku EU. Upotreba sankcija kao sredstva $u$ spoljnoj i bezbednosnoj politici usvojena je $u$ programskom dokumentu EU pod nazivom - Principi upotrebe restriktivnih mera (eng. Principles on the Use of Restrictive Measures), nekoliko meseci posle usvajanja Evropske strategije bezbednosti. ${ }^{70}$ Proliferaciona kriza na Korejskom poluostrvu počela je 1994. godine od kada su čitavo upravljanje kizom, koja traje i danas, preuzele SAD. Sledstveno tome, EU je vodila nezapaženu ulogu koja se svodila na podržavanje američkih aktivnosti i usvajanje konvergentnih mera sankcionisanja. EU je postala članica izvršnog odbora Organizacije za energetski razvoj Korejskog poluostrva (KEDO) 1997. godine. ${ }^{71}$ KEDO je formiran 1995 . godine kao deo dogovora uzmeđu SAD i Severne Koreje o konstrukciji dva lakovodna reaktora u zamenu za demontiranje nuklearnog programa. Doprinos EU u ovom projektu bio je 122 miliona dolara što je bio četvrti najveći iznos u tu svrhu posle doprinosa

${ }^{68}$ Oliver Meier, "European Efforts to Control the Spread of Enrichment and Reprocessing Technologies", UNISCI Discussion Papers, No. 30, October 2012.

${ }^{69}$ Harald Muller, "The European Union and Nuclear Non-Proliferation and Disarmament", in: V.R. Raghavan (ed.), Nuclear Disarmament: India-EU Perspectives, Vij books, New Delhi, pp. 27-49.

70 "Sanctions: how and when the EU adopts restrictive measures", European Council, Internet, https://www.consilium.europa.eu/en/policies/sanctions/, 12/3/2020.

${ }^{71}$ Agreement on the Establishment of the Korean Peninsula Energy Development Organization, 9th March 1995, Internet, http://www.kedo.org/pdfs/Establishment

40 KEDO.pdf, 20/3/2020. 
Južne Koreje, Japana i SAD. ${ }^{72}$ Finansijsko učešće u KEDO bio je prvi vidljiv korak EU u domenu sprečavanja proliferacije na Korejskom poluostrvu, što nije rešilo problem jer je Severna Koreja nastavila sa nuklearnim programom, a to je kulminiralo 2003. godine napuštanjem Sporazuma o neširenju nuklearnog oružja. EU nikada nije bila deo "Six-Party“ razgovora koji su otpočeli 2003. godine nakon formalnog napuštanja neproliferacionog režima, a koje pored Severne Koreje čine Južna Koreja, Japan, SAD, Rusija i Kina. Uloga EU svodila se na uvođenje sankcija, ali tek nakon što su one odobrene u Savetu bezbednosti UN. Restriktivnije sankcije protiv Severne Koreje uvođene su u više talasa rezolucijama Saveta bezbednosti, od momenta prvog testa nuklearne bombe 2006. godine, drugog 2009, trećeg 2013. godine, četvrtog i petog 2016. i šestog testa 2017. godine. ${ }^{73} \mathrm{EU}$ u proliferacionoj krizi na Korejskom poluostrvu nije učestvovala u pregovorima, ali se sve više pominje ta ideja s obzirom na to da je problem još uvek aktuelan. ${ }^{74}$ Doprinos u tom smislu ostaće mizeran sve dok EU kao entitet ne uzme direktno učešće u razgovorima.

Iran

Za razliku od slučaja Severne Koreje, EU je u iranskoj nuklearnoj krizi imala zapaženu, donekle i ključnu ulogu kao pregovarač. EU je sa Iranom otpočela pregovore o zaključivanju ugovora o trgovini i saradnji koji su prekinuti 2003. godine zbog krize uzrokovane iranskim obogaćivanjem uranijuma. ${ }^{75}$ Velika evropska trojka (Ujedinjeno Kraljevstvo, Nemačka i Fransuska) poznata kao E3 preuzela je vodeću ulogu u rešavanju krize, a glavni koordinator je bio Visoki predstavnik za spoljnu i bezbednosnu politiku EU. Glavni okvir ovih pregovora bila je podrška Iranu za razvoj civilne nuklearne energije, saradnja u oblasti tehnologije i snažnije ekonomsko vezivanje. Zauzvrat, Iran bi trebalo da odustane od aspiracija razvijanja nuklearnog oružja. Uspeh je načinjen već 2004. godine kada je Iran objavio nameru da suspenduje proces daljeg obogaćivanja uranijuma i kada

${ }^{72}$ S. Yoon and J. Suh, "Nuclear Non-proliferation", in: T. Christiansen, E. Kirchner and P. Murray (eds.), The EU-Asia Handbook, Palgrave, Houndmills, 2013, pp. 406-420.

${ }^{73}$ Protiv Severne Koreje uvođene su sankcije $\mathrm{u}$ više talasa rezolucijama Saveta bezbednosti UN i to: 2006, 2009, 2013, 2016. i 2017. godine. Videti: Andrea Charron, United Nations Sanctions and Conflict, Routledge, London, 2011; "Security Council Tightens Sanctions on Democratic People's Republic of Korea, Unanimously Adopting Resolution 2397", UN Security Council, 22 December 2017, Internet, https:/ / www.un. org/press/en/2017/sc13141.doc.htm, 15/4/2020.

74 "It's Time for the European Union to Talk to North Korea", 38 North, 2nd March 2020, Internet, https://www.38north.org/2020/03/eu030220/, 22/4/2020.

${ }^{75}$ T. Sauer, "The Impact of the European Union on Iran's Nuclear Programme", in: R. Parsi and J. Rydqvist (eds.), Iran and the West, FOI, Stockholm, pp. 93-104. 
je potpisan ugovor u Parizu. Pariski sporazum predviđao je da Iran zaustavi obogaćivanje uranijuma i potpiše Dodatni protokol o stalnim inspekcijama IAEA.$^{76}$ Promena se dogodila 2005. pobedom Mahmuda Ahmadinedžada na izborima za predsednika Irana koji je objavio da pokreće obogaćivanje uranijuma do nivoa od 20\%. E3 je pozvala na poštovanje Pariskog sporazuma ali se Ahmadinedžad nije povinovao, što je uzrokovalo uvođenje sankcija Iranu 2006. godine kada EU prestaje da bude jedini pregovarač i kada se u pregovore uključuju SAD, Rusija i Kina. Pregovaračka formula E3 biva zamenjena formulom E3+3 kako ostaje sve do danas. Ekonomski interes EU, čije su kompanije veoma aktivne u području Bliskog istoka, jeste da ne dođe do nekog većeg sukoba poput invazije na Irak iz 2003. godine u cilju prevencije sticanja OMU. Stoga su EU uvele veoma oštre sankcije Iranu u više talasa, neretko mnogo rigoroznije nego što su to radile SAD, a sve u cilju očuvanja neproliferacionog režima i izbegavanja vojnog sukoba na relaciji SAD-Iran ili Izrael-Iran. ${ }^{77}$ Sankcije EU prema Iranu uticale su da Iran promeni svoje evropske ekonomske partnere i preorijentiše ekonomsku saradnju na kompanije iz Kine. Iran je pretrpeo ozbiljnu ekonomsku štetu zbog sankcija i nakon talasa sankcija EU iz 2012. godine, iranske banke su izbačene iz sistema međunarodnog bankarskog transfera novca (SWIFT). Iranska valuta je te godine pala više od 70\%. ${ }^{78}$ Sankcije $u$ energetskom sektoru su uzrokovale da međunarodni uvoznici nafte prestanu saradnju sa Iranom, čiji bruto društveni proizvod u najvećoj meri sačinjava izvoz nafte. Politički pritisci EU u formi E3 kombinovani sa ekonomskim sankcijama dovele su Iran za pregovarački sto 2013. godine kada je Hasan Rohani pobedio na izborima za predsednika (u velikoj meri zbog ekonomskih problema). Iran je potpisao privremeni sporazum u Ženevi u novembru 2013. godine sa E3+3 u kome se obavezao da zaustavi obogaćivanje uranijuma, izgradnju novih centrifuga i dozvoli inspektorima IAEA nesmetane obilaske nuklearnih postrojenja $u$ Natancu i Fordovu. ${ }^{79}$ Privremeni sporazum je zamenjen sporazumom o denuklearizaciji iz Beča

76 "Communication dated 26 November 2004 received from the Permanent Representatives of France, Germany, the Islamic Republic of Iran and the United Kingdom concerning the agreement signed in Paris on 15 November 2004", IAEA, 26th November 2004, Internet, https:/ / www.iaea.org/sites/default/files/publications/ documents/infcircs/2004/infcirc637.pdf, 1/3/2020.

${ }^{77}$ Johan Bergenas, “The European Union's Evolving Engagement with Iran", Nonproliferation Review, Vol. 17, No. 3, 2010, p. 503.

${ }^{78}$ Videti: Nader Habibi, "A Closer Look at Sanctions Relief", Iran Matters, 9 December 2013, Internet, https:// www.belfercenter.org/publication/closer-look-sanctions-relief, 20/3/2020.

${ }^{79}$ Frederick Dahl and Justyna Pawlak, "West, Iran activate landmark nuclear deal", Reuters, 20 January 2014, Internet, https:/ / www.reuters.com/article/us-iran-nuclear/

42 west-iran-activate-landmark-nuclear-deal-idUSBREA0J00420140120, 24/3/2020. 
potpisan 15. jula 2015. godine (eng. Joint Comprehensive Plan of Action). ${ }^{80}$ SAD su napustile ovaj ugovor 2018. godine, pa je EU ostala najznačajniji garant njegovog sprovođenja koje je zapalo u ćorsokak. ${ }^{81}$ Epilog iranskog slučaja još uvek nije poznat, ali je EU u njemu od samog početka igrala značajnu, a u nekim momentima presudnu ulogu u denuklearizaciji i pacifikaciji čitavog regiona Bliskog istoka.

\section{Zaključna razmatranja}

Postoji sumnjičavost prema nastupanju Evropske unije u pitanjima koja se tiču bezbednosti zbog različitih pogleda na postojeće konflikte, raznovrsnih bezbednosnih kultura i tradicija i nekoherentnih (neretko i suprotstavljenih) interesa u spoljnim politikama. Međutim, na polju sprečavanja širenja nuklearnog, hemijskog i biološkog naoružanja, postoji konsenzus među svim članicama Evropske unije.

Evropska strategija bezbednosti, Strategija protiv širenja oružja za masovno uništenje i klauzula OMU, predstavljaju plod koherentnog pogleda svih članica EU na problem proliferacije, iako je u retkim slučajevima bilo praktičnog razmimoilaženja kao u slučaju Indije. Borba protiv širenja OMU unutar Evropske unije ima status aksioma i čini okosnicu učvršćivanja još uvek nekonzistentne Zajedničke spoljne i bezbednosne politike. Aktivan otpor proliferaciji OMU takođe je jedan od neophodnih uslova za sve buduće članice, ali i partnere koji sa EU potpisuju mešovite sporazume.

Aktivnosti Evropske unije kao nadnacionalnog entiteta na polju neproliferacije, iako novijeg datuma, dovele su do opipljivih razultata od kojih je kruna uspeha potpisivanje sporazuma sa Iranom. Poseban odnos prema problemu i aktivan otpor širenju oružja za masovno uništenje, EU je napravila tek nakon terorističkog napada na SAD, kada je shvatila da su „slabi sposobni da povrede jake“. Prelomna godina je 2003. kada je EU usvojila navedene akte kao smernice za delovanje, iako je i pre toga bila aktivna kao finansijer organizacija kao što su IAEA, KEDO i Organizacija za zabranu hemijskog naoružanja. Doprinos EU na ovom polju nije zanemarljiv, a prioritetno mesto sprečavanja širenja OMU u evropskoj bezbednosnoj strategiji navodi na zaključak da će EU i u budućim kriznim žarištima imati značajnu ulogu u sprečavanju proliferacije nuklearnog, hemijskog i biološkog oružja.

80 "Joint Comprehensive Plan of Action", Vienna, 14 July 2015, Internet, https:/ / www.europarl.europa.eu/cmsdata/122460/full-text-of-the-iran-nucleardeal.pdf, 7/5/2018.

${ }^{81}$ Mark Landler, "Trump Abandons Iran Nuclear Deal He Long Scorned", New York Times, 8 May 2018, Internet, https:/ / www.nytimes.com/2018/05/08/world/middle east/trump-iran-nuclear-deal.html, 12/4/2020. 


\section{Bibliografija}

"1540 Committee", UN Security Council Committee established pursuant to resolution 1540, Internet, https:/ / www.un.org/en/sc/1540/about-1540committee/general-information.shtml, 11.4.2020.

"Action Plan for the Implementation of the Basic Principles for an EU Strategy against Proliferation of Weapons of Mass Destruction", Council of the European Union, 10354/1/03, Brussels, 13 June 2003, p. 6, Internet, http://www.sussex.ac.uk/Units/spru/hsp/documents/20030616\%20Action\%20plan.pdf, 22/4/2020.

"Agreement on the Establishment of the Korean Peninsula Energy Development Organization", 9th March 1995, Internet, http://www.kedo.org/pdfs/EstablishmentKEDO.pdf, 20/3/2020.

"Committed to complete and verifiable destruction", OPCW, Internet, http://www.opcw.org/our-work/demilitarisation/, 6/5/2020.

"Communication dated 26 November 2004 received from the Permanent Representatives of France, Germany, the Islamic Republic of Iran and the United Kingdom concerning the agreement signed in Paris on 15 November 2004", IAEA, 26th November 2004, Internet, https://www.iaea.org/sites/default/files/publications/documents/inf circs/2004/infcirc637.pdf, 1/3/2020.

"Comprehensive Nuclear-Test-Ban Treaty", General Assembly of the United Nations, Resolution 50/245, NY, 17 September 1996, Internet, http:/ / www.ctbto.org/fileadmin/content/treaty/treaty_text.pdf, 6/5/2020.

"Council conclusions and new lines for action by the European Union in combating proliferation of weapons of mass destruction and their delivery systems", Council of the European Union, 17172/08, Brussels, 17 December 2008.

"Disarmament, Non-Proliferation and Arms Export Control", European External Action Service, 8.8.2016., Internet, http:/ / eeas.europa.eu/nonproliferation-and-disarmament/special_envoy_en.htm, 11/4/2020.

"EU aide worried by calls to drop India WMD clause", Reuters, 2 March 2007, Internet, http://www.bilaterals.org/spip.php?article7311, 8/4/2020.

"EU INTCEN", fact sheet, Internet, http://statewatch.org/news/ 2016/may/eu-intcen-factsheet.pdf, 10/2/2020.

"EU Strategy against the Proliferation of Weapons of Mass Destruction", European Council, Brussels, 12 December 2003, Internet, https:// www.nonproliferation.eu/hcoc/wp-hcoc/uploads/EUStrategy-Against-the-Proliferation-of-WMD-2003.pdf, 4/42020.

"EU Strategy against the Proliferation of WMD: monitoring and enhancing consistent implementation", Council of the European Union, concept paper, no. 16694/06, Brussels, 12 December 2006, Internet, http:/ / register. 
consilium.europa.eu/doc/srv?l=EN\&f=ST\%2016694\%202006\%20INIT, $15 / 4 / 2020$.

"European Comission", Trade policy, https://ec.europa.eu/trade/policy/ countries-and-regions/countries/india/, Internet, 16.4.2020.

"European External Action Service", HQ Organizational chart, Internet, https: / / eeas.europa.eu/sites / eeas/files/2020-01-05-eeas-2.0_ orgchart.pdf, 12.4.2020.

"European Security Strategy", European Council, Brussels, 12 December 2003, Internet, http://consilium.europa.eu/uedocs/cmsUpload/783 67.pdf, 12/3/2020.

"Inventory of Agreements Containing the Weapons of Mass Destruction Clause", Treaties Office database, G.AFFGEN. 3 Legal Affairs Division, Internet, https://ec.europa.eu/world/agreements/ClauseTreatiesPDF GeneratorAction.do?clauseID=28, 18.4.2020.

"It's Time for the European Union to Talk to North Korea", 38 North, 2nd March 2020, Internet, https://www.38north.org/2020/03/eu030220/, 22/4/2020.

"Joint Comprehensive Plan of Action", Vienna, 14 July 2015, Internet, https://www.europarl.europa.eu/cmsdata/122460/full-text-of-theiran-nuclear-deal.pdf, 7/5/2018.

"Mainstriming non-proliferation policies into the EU's wider relations with third countries", Council of the European Union, no. 14997/03, Brussels, 19 November 2003, http://www.sussex.ac.uk/Units/spru/hsp/ documents/2003-1117\%20Mainstreaming.pdf, Internet, 6/2/2020.

"Peaceful uses of nuclear technology", General Secretariat of the Council, publications 049/2012, Brussels, April 2012.

"Public Statement of the 2019 NSG Plenary - Nur-Sultan", Kazakhstan, Internet, https://www.nuclearsuppliersgroup.org/en/news/246-public -statement-of-the-2019-nsg-plenary-nur-sultan-kazakhstan, 1/4/2020.

"Resolution 1540", UN Security Council, 28 April 2004, Internet, https://www.un.org/ga/search/view_doc.asp?symbol=S/RES/1540\% 20 (2004), 6/5/2020.

"Sanctions: how and when the EU adopts restrictive measures", European Council, Internet, https://www.consilium.europa.eu/en/policies/ sanctions/, 12/3/2020.

"Security Council Tightens Sanctions on Democratic People's Republic of Korea, Unanimously Adopting Resolution 2397", UN Security Council, 22 December 2017, Internet, https://www.un.org/press/en/2017/ sc13141.doc.htm, 15/4/2020.

"Size and population", European Union, Internet, https://europa.eu/ european-union/about-eu/figures/living_en, 11/1/2020. 
“The Biological Weapons Convention", UN Office for Disarmament Affairs, Internet, https://www.un.org/disarmament/wmd/bio/,7/5/2020.

"The European Union Strategy against Proliferation of Weapons of Mass Destruction: effective multilateralism, prevention and international cooperation", General Secretariat of the Council, brochure, Brussels, November 2008.

"Treaty on the Non-Proliferation of Nuclear Weapons", United Nations, 1968, Internet, https://www.un.org/disarmament/wmd/nuclear/ $\mathrm{npt} /, 26 / 4 / 2020$.

Bailes, A. J. K., "The European Security Strategy: An Evolutionary History", Policy Paper, No. 10, SIPRI, Stockholm, 2005.

Bergenas, Johan, “The European Union's Evolving Engagement with Iran", Nonproliferation Review, Vol. 17, No. 3, 2010, pp. 491-512.

Charron, Andrea, United Nations Sanctions and Conflict, Routledge, London, 2011.

Dahl, Frederick and Justyna, Pawlak, "West, Iran activate landmark nuclear deal", Reuters, 20 January 2014, Internet, https://www.reuters.com/ article/us-iran-nuclear/west-iran-activate-landmark-nuclear-dealidUSBREA0J00420140120, 24/3/2020.

European Centre for Disease Prevention and Control, An Agency of the European Union, Internet, http://www.ecdc.europa.eu/en/aboutus /Pages/AboutUs.aspx, 2/4/2020.

Grip, Lina, "The EU Non-Proliferation Clause: A Preliminary Assessment", Background Paper, SIPRI, November 2009.

Habibi, Nader, "A Closer Look at Sanctions Relief", Iran Matters, 9 December 2013, Internet, https://www.belfercenter.org/publication/closer-looksanctions-relief, 20/3/2020.

Jackson, Richard, Nuclear biological, and chemical defense in the 21 st. Century, US Army War College Center for Strategic Leadership, Carlisle, PA, 1994.

Keller, William, "Anatomy of a Terrorist Attack: An in-Depth Investigation into the London and Madrid Subway Bombings of 2005 and 2004", working paper, Matthew B. Ridgway Center, University of Pittsburgh, 2006.

Landler, Mark, "Trump Abandons Iran Nuclear Deal He Long Scorned", New York Times, 8 May 2018, Internet, https:/ / www.nytimes.com/2018/ 05/08/world/middleeast/trump-iran-nuclear-deal.html, 12/4/2020.

Lugar, Richard, "Cooperative Threat Reduction and Nuclear Security", Georgetown Journal of International Affairs, Vol. 10, No. 1, 2009, pp. 183-189.

Meier, Oliver, "European Efforts to Control the Spread of Enrichment and Reprocessing Technologies", UNISCI Discussion Papers, No. 30, October 462012. 
Muller, Harald, "The European Union and Nuclear Non-Proliferation and Disarmament", in: V.R. Raghavan (ed.), Nuclear Disarmament: India-EU Perspectives, Vij books, New Delhi, pp. 27-49.

Petrović, Dragan i Bogdan, Stojanović, Ravnoteža nuklearne moći SAD i Rusije (SSSR), Pešić i sinovi, Beograd, 2012.

Pletcher, Kenneth, "Tokyo subway attack of 1995", March 13, 2020, Internet, https:// www.britannica.com/event/Tokyo-subway-attack-of-1995, $15 / 3 / 2020$.

Sauer, T., "The Impact of the European Union on Iran's Nuclear Programme", in: R. Parsi and J. Rydqvist (eds.), Iran and the West, FOI, Stockholm, pp. 93-104.

Stern, Jessica, The Ultimate Terorists, Harvard University Press, 1999.

Vukčević, Dejana, Bezbednost i Evropska unija, Institut za političke studije, Beograd, 2008.

Yoon, S. and Suh J., "Nuclear Non-proliferation", in: T. Christiansen, E. Kirchner and P. Murray (eds.), The EU-Asia Handbook, Palgrave, Houndmills, 2013, pp. 406-420.

\title{
NUCLEAR DEPROLIFERATION AND EU POLICY FOR NON-PROLIFERATION OF WEAPONS OF MASS DESTRUCTION IN THE CONTEXT OF RELATIONS WITH INDIA, PAKISTAN, IRAN AND NORTH KOREA
}

\begin{abstract}
This paper aims to present the activities of the European Union in the field of preventing the proliferation of weapons of mass destruction. In addition to the analysis of institutional and legal mechanisms established from 2003 onwards, the practical effect of the European Union in preventing the proliferation of Armageddon weapons is also investigated. The uneven role and results achieved in various crisis hotspots, such as North Korea, Iran, India and Pakistan, leave room for different forecasts of future EU action. A good starting point and a basic consensus of all members regarding the proliferation of weapons of mass destruction give a reason for optimism in the analysis. Therefore, the paper explores the relationship between established capacities, practical policies, and future crisis sites related to the proliferation of weapons of mass destruction.

Keywords: European Union, weapons of mass destruction, proliferation, nuclear program, North Korea, Iran, India, Pakistan.
\end{abstract}

